\title{
Coral reefs in crisis: reversing the biotic death spiral
}

\section{Mark E Hay* and Douglas B Rasher}

\author{
Address: School of Biology, Georgia Institute of Technology, Atlanta, GA 30332, USA \\ *Corresponding author: Mark E Hay (mark.hay@biology.gatech.edu) \\ FI000 Biology Reports 2010, 2:7I (doi:10.34I0/B2-7I)
}

The electronic version of this article is the complete one and can be found at: http://fl000.com/reports/biology/content/2/7I

\begin{abstract}
Coral reefs are disappearing due to global warming, overfishing, ocean acidification, pollution, and interactions of these and other stresses. Ecologically informed management of fishes that facilitate corals by suppressing seaweeds may be our best bet for bringing reefs back from the brink of extinction.
\end{abstract}

\section{Introduction and context}

Coral reefs are declining dramatically due to cascades of interacting stresses ranging from global warming, overfishing, pollution, and ocean acidification to catastrophic events like the oil spill in the Gulf of Mexico. One of the world's most productive, species-rich, and visually spectacular ecosystems is in unprecedented global decline [1-8], mandating immediate and informed action. Accidents like the oil spill in the Gulf of Mexico capture public attention and bring needed focus to declining marine ecosystems. But the insidious, day-to-day insults from overfishing, elevated $\mathrm{CO}_{2}$, and nutrient pollution may be just as devastating because they are chronic and omnipresent. Reef ecologists are rapidly gaining new insights into the mechanisms driving reef decline and by doing so are discovering additional options for protecting and restoring coral reef ecosystems. Strategic management of fish stock across broader spatial scales may be our best bet for bringing reefs back from the brink of ecological extinction in the near term. Long-term, we will also need to address drivers of climate change and ocean acidification $[1,9]$.

Over the last 30-40 years, coral cover in the Caribbean has declined by $80 \%$ [6] and in the Indo-Pacific by $50 \%$ $[4,7]$. In the early 1980s, the Caribbean had such huge stands of elkhorn and staghorn corals (Acropora palmate and A. cervicornis, respectively) that entire reef zones were named after these species and patches the size of city blocks were common. Today, both species are scarce and a patch the size of a desk merits gathering graduate students for a viewing. In the early 1980s, these were the two most abundant corals in the Caribbean. In 2006, both species were listed as vulnerable under the US endangered species act and in 2009 both were elevated to threatened status. At present, $30 \%$ of the world's corals are at elevated risk of extinction [8]. This is an unprecedented decline; it would be the ecological equivalent of losing pine trees from the southeastern United States, hardwood trees from New England, or aspens from the Rocky Mountains - all in little more than a decade. Coral decline affects not only coral reefs; the US Commission on Ocean Policy estimates that coral reefs provide a staggering $\$ 375$ billion per year in goods and services.

Some reasons for coral loss are better documented than others [2,5,9-11], but it is clear that a host of both global and local phenomena play a part. This mix of local-scale stresses (which can be altered by local management efforts) and global-scale stresses (which local managers cannot control) makes it challenging to prevent, and especially to reverse, coral decline. However, if we don't act both quickly and wisely, coral reefs will be gone. The frequency and scale of climate-induced bleaching of coral reefs in recent decades has affected hundreds of reefs and at times whole ocean basins $[1,9]$. But bleaching is just one part of the problem. Coral diseases have also increased dramatically, often in association with increased temperatures and coral bleaching [2]. 
Additionally, corals decline and seaweeds proliferate following any of a host of disturbances such as coral bleaching, epidemics of coral disease, or overfishing of reef herbivores [2-5,10,11]. Once reefs become dominated by seaweeds, negative feedback reinforces seaweed-dominance and produces a coral 'death spiral' from which recovery is difficult (see Figure 1). Once seaweed growth outpaces the ability of reef herbivores to control seaweed biomass, seaweeds bloom and reef degradation can be quick and difficult to reverse because seaweeds directly damage corals $[5,12,13]$ and also suppress colonization of their larvae [14-16], thus preventing coral recovery. Corals are foundation species that provide the physical structure and habitat complexity upon which fishes and other reef species depend. Therefore, the decline in corals leads to a decline in herbivorous fishes $[5,17,18]$, which leads to even more seaweeds, which leads to further decline in corals as seaweeds shade, abrade, and chemically poison remaining corals as well as suppressing their ability to reproduce and prevent the recruitment and survival of their larvae [10,11,13-15]. Many researchers have documented this coral reef death spiral, when herbivorous fish were experimentally removed on a small scale $[10,11,13]$, as well as over large scales in the Caribbean following overfishing or herbivore disease [1,3-5]. There is considerable concern that similar losses are now beginning world-wide, with global climate change and ocean acidification driven by increased $\mathrm{CO}_{2}$ production presenting even larger challenges to conservation and recovery.

\section{Major recent advances}

Marine protected areas are necessary but not sufficient to save coral reefs. Conservation and restoration of coral reefs is currently focused on establishing marine

Figure I. Feedbacks producing the biotic death spiral versus the resilience of a healthy coral reef

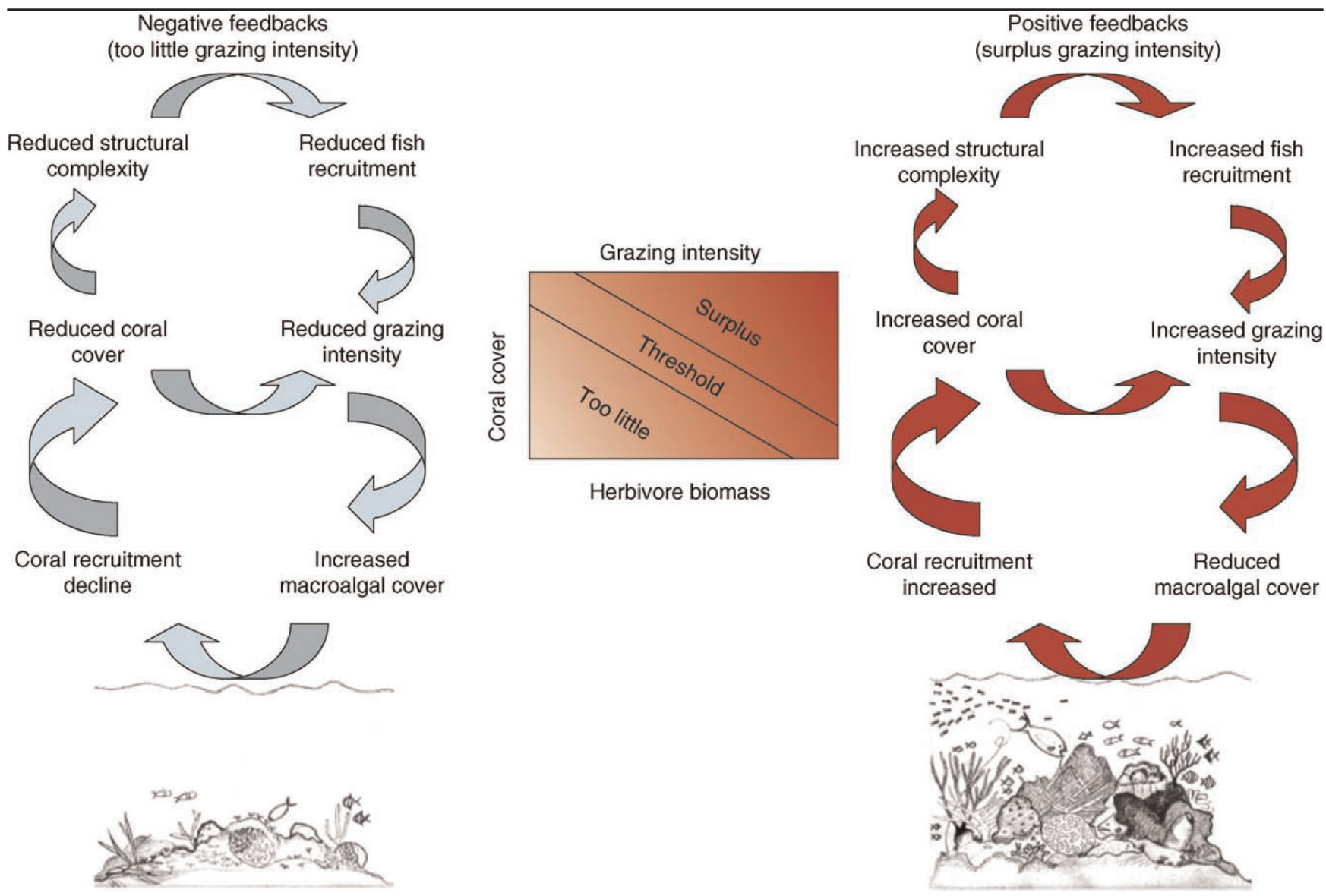

Schematic of the biotic interactions producing positive or negative feedbacks that drive a reef toward either an unhealthy state of seaweed dominance, with declining corals, fishes, and structural complexity (left side of image), or toward a resilient healthy state of coral dominance, with few seaweeds, many fishes, and a high structural complexity formed by coral growth (right side of image). Rate of herbivory is the critical interaction determining whether the feedback is positive or negative. Reprinted from [5], (C) 2008, with permission from Elsevier. 
protected areas where local stresses such as fishing and pollution are reduced or eliminated. However, these boundaries affecting human's use of the area don't afford reefs with protection from stresses such as pathogens, storms, ocean-acidification, and elevated sea-surface temperatures that do not stop at political or regulatory borders. This being the case, the effectiveness of marine protected areas in lessening global-scale stresses can be questioned $[17,20]$. However, recent analyses demonstrate that marine protected areas are useful despite global-scale stresses, and also suggest possible improvements in management options for conserving healthy reefs and reviving damaged ones [21,22].

Marine protected areas are assumed to serve two critical functions for coral reefs: first, to protect the community in the marine protected area from further damage, and second, to allow the corals and other reef organisms in the marine protected area to reproduce and provide larvae that can facilitate recovery of adjacent communities. The first function recently has been demonstrated; the second is more debatable.

Recent studies show that marine protected areas indeed help increase reef resistance to, and recovery from, global-scale stresses, at least within the protected areas $[21,22]$. Elizabeth Selig and John Bruno from the University of North Carolina at Chapel Hill recently completed a world-wide comparison of coral cover inside 310 marine protected areas versus similar unprotected reefs [21]. They found that average coral cover remained constant over recent years in marine protected areas while cover on unprotected reefs declined. Additionally, coral cover in older marine protected areas tended to be higher than in newer ones. This analysis covered 1969-2006 so it includes the severe global bleaching event of 1998. Bleaching occurs both inside and outside marine protected areas but coral recovery was quicker inside marine protected areas due to the greater abundance of herbivorous fishes, which initiated a feeding cascade that reduced seaweeds and prevented their suppression of corals $[5,10,11,23-25]$.

Maintaining an intact food web (a complex of interrelated food chains) of diverse fishes can even diminish coral disease. Laurie Raymundo [26] and her colleagues at the University of Guam observed a higher frequency of coral diseases on more heavily fished reefs. In particular, they found that overfishing removed predators that in turn were controlling a group of coral-feeding fishes. The coral-feeding fishes, which became more abundant with their predators removed, vectored coral diseases as they fed.

\section{Advances in understanding how the damage is done}

Another recent advance highlights the way multiple man-made stresses exacerbate damage to coral reefs. Although bleaching is a response to high sea surface temperatures associated with global-scale stresses, local man-made stresses also have an effect, so even local-scale management can affect coral response to global-scale disturbance. In a recent overview of coral bleaching and climate data, a group of collaborating marine scientists lead by Jessica Carilli from Scripps Institution of Oceanography in San Diego noticed that the first large scale bleaching in the Caribbean occurred in 1998 despite the fact that both 1937 and 1958 were warmer years [27]. This suggested that temperature was not the sole driver of bleaching. Further analysis indicated that bleaching was better explained by temperature together with nearby human population density than by temperature alone, suggesting that chronic local stresses were depressing heat tolerance and increasing the risk of coral bleaching. Local man-made stresses also slowed coral recovery following a bleaching event. After the Caribbean bleaching of 1998, growth rates of the important reefbuilding coral Montastraea faveolata took 8 years or more to recover in areas with more man-made disturbance, but only 2-3 years in areas experiencing less man-made stress. A study along the Great Barrier Reef [22] found a similar relationship; a synergism between heat stress and nutrient flux appeared to be a major causative mechanism for the geographic pattern of coral bleaching.

While it is well established that stresses such as bleaching, disease, overfishing, and pollution tend to suppress corals and enhance seaweeds, the mechanisms involved have been clarified only recently. Meta-analysis of experiments manipulating herbivorous fishes and nutrients show that the former are critical for suppressing seaweeds on reefs and that the latter play a much lesser role [28]. Different types of investigations emphasize this same point. Field experiments in which herbivorous reef fishes were experimentally excluded from 4-25 $\mathrm{m}^{2}$ caged areas on natural reefs (to represent the effects of overfishing) demonstrated a dramatic increase in seaweeds and a significant decline in coral fitness within the cages via changes in herbivorous fishes alone $[10,11]$. When we manipulated the quantity and species of herbivorous fish in large enclosures on deeper $(17 \mathrm{~m})$ natural reefs in the Florida Keys, we saw that a mix of herbivores with complementary diets were especially efficient at preventing seaweed growth and aiding corals [10]. Corals in enclosures with the mix of herbivore species grew 22\% in 10 months and experienced no mortality. In contrast, corals in enclosures without herbivores shrank in size by more than $20 \%$ and experienced more than $20 \%$ mortality in the same 
period [10]. Working on shallower reef flats in Australia, Terence Hughes and his collaborators at James Cook University demonstrated similar impacts of fish grazing; herbivorous fishes were critical for suppressing seaweeds and preventing them from suppressing corals [11].

These studies have shown a clear association between seaweed abundance and coral decline, but until recently the mechanisms producing such declines were unclear. It was well known that seaweeds suppressed the recruitment and survival of juvenile corals [11,14-16] but how seaweeds damaged established corals was unclear [5]. In recent field manipulations in both the Caribbean and tropical Pacific, we placed seaweeds in contact with corals and demonstrated that numerous common seaweeds caused coral bleaching and sometimes death via transfer of toxic compounds from seaweed surfaces [13]. Other studies demonstrated that some seaweeds also transmit coral disease in the field or, under laboratory conditions, exude metabolites that stimulate coral-damaging microbes $[29,30]$. Thus, seaweeds not only suppress recruitment of coral larvae, but also can damage older corals.

The general consensus emerging from many studies on many different types of coral reefs is that reefs need to be managed for resiliency to a host of anthropogenic and natural stresses and that a critical aspect of this is preserving natural densities and diversities of herbivorous fishes that will keep seaweeds in check and promote coral recruitment $[4,5,10,11,23-26]$.

\section{Advances in understanding reef resiliency}

The second purpose of marine protected areas, to help adjacent areas recover their natural community composition and function, is inadequately demonstrated and can be questioned $[17,20]$. Marine protected areas can provide 'spill-over' of fish to adjacent areas, helping replenish fish stocks. However, that spill-over is often too rapidly harvested [31] to suppress seaweed and subsequently enhance coral growth in unprotected areas. Thus, marine protected areas may fail to help adjacent reefs recover unless stocks of critical herbivorous fishes are elevated enough to make these areas receptive to recruiting coral larvae [5,32].

Enhancing fish stocks is critical for preventing or reversing coral loss, but some fishes are more critical than others in this process. Experimental removal and reintroduction of herbivorous fishes alone can induce regime shifts from corals to seaweeds or from seaweeds back toward corals $[10,11,19]$, but recent research also indicates that herbivorous fish diversity [10], identity [33], and size [34] can all be critical for controlling seaweeds and facilitating corals. In our field enclosures we found that a mix of herbivores with complementary diets facilitated both the survival and growth of corals, while enclosures with equal densities and masses of single herbivore species did not [10]. Fish size within a species can also be critical. Large fish are disproportionately better grazers than small fish - for some parrotfish, it takes 75 fish of $15 \mathrm{~cm}$ length to graze as much as one fish of $35 \mathrm{~cm}$ length [34]. It follows that fishing methods targeting larger individuals will disproportionately suppresses grazing. This suggests that reefs may need long-term protection from fishing before grazers achieve a size at which they are most effective $[23,31,34]$. To be healthy, coral reefs must have a mix of bioeroding fishes that scrape away dead coral and expose hard surfaces, scraping fishes that limit filamentous algae and sediments on these hard surfaces, and grazers that remove macroalgae [4].

Recent studies make another point relevant for management: it seems that the fish that prevent seaweed taking over reefs in the first place may not be the same fish that can reverse the shift once it occurs. When we manipulated the diversity and identity of herbivorous fishes in enclosures on a Caribbean reef and determined their effects on both the established reef community and on uncolonized substrates newly placed on the reef, herbivore diversity was critical for suppressing seaweeds on the established community but less so for the newly colonizing community [10,35]. Additionally, the herbivore species that most strongly suppressed larger seaweeds in the mature community had the least impact on larger seaweeds colonizing the new substrate. Even more dramatic was work by David Bellwood and colleagues of James Cook University in Australia. When they caged large herbivorous fishes out of reef areas for long periods, an algal forest developed and harmed corals; however, when they removed the cages, this algal forest was consumed primarily by a species of reef fish that had not previously been recognized as herbivorous [33].

\section{Future directions}

Reefs need to be managed for resilience to a host of interacting local and global stresses; the rapid losses, slow recoveries, and host of accelerating stresses make it urgent that we develop efficient strategies for intervention, based on an understanding of the ecology of coral reefs. While marine protected areas are critical to success, they alone are unlikely to allow reef survival because most are too isolated, too small, and cannot adequately leverage recovery of adjacent areas. We need to find effective ways to make damaged reefs more receptive to larval corals and thus better able to stop the death spiral that is occurring on today's reefs (Figure 1); this will involve limiting the 
harvest of a critical mix of reef herbivores that prevent seaweeds from blooming on coral reefs. Because almost all major stresses shift reefs from corals to seaweeds, a better understanding of the processes and mechanisms underlying this shift, and its reversal, will be critical for preventing and reversing losses of coral reefs. To optimize our management efforts, we need information on the mechanisms involved in seaweed-coral interactions at all stages of the life cycle, the seaweeds that are most damaging to corals, and the mix of herbivorous fishes that consume the most damaging seaweeds. In short, we need proactive management that goes beyond establishing marine protected areas and hoping for the best.

\section{Competing interests}

The authors declare that they have no competing interests.

\section{Acknowledgments}

This work was supported by the US National Science Foundation (OCE 0929119), the National Institutes of Health (U01 TW007401-01), and the Teasley Endowment to the Georgia Institute of Technology.

\section{References}

I. Hoegh-Guldberg O, Mumby PJ, Hooten AJ, Steneck RS, Greenfield P, Gomez E, Harvell CD, Sale PF, Edwards AJ, Caldeira K, Knowlton N, Eakin CM, Iglesias-Prieto R, Muthiga N, Bradbury RH, Dubi A, Hatziolos ME: Coral reefs under rapid climate change and ocean acidification. Science 2007, 318: 1737-42.

\section{FI000 Factor 6.0 Must Read \\ Evaluated by Russell Moll 08 Jan 2008}

2. Harvell $D$, Jordán-Dahlgren E, Merkel S, Rosenberg E, Raymundo L, Smith G, Weil E, Willis B: Coral diseases, environmental drivers, and the balance between coral and microbial associates. Oceanography 2007, 20:172-95.

3. Jackson JBC, Kirby MX, Berger WH, Bjorndal KA, Botsford LW, Bourque BJ, Bradbury RH, Cooke R, Erlandson J, Estes JA, Hughes TP, Kidwell S, Lange CB, Lenihan HS, Pandolfi JM, Peterson CH, Steneck RS, Tegner MJ, Warner RR: Historical overfishing and the recent collapse of coastal ecosystems. Science 200I, 293:629-37.

\section{FI000 Factor 6.0 Must Read \\ Evaluated by Helen Yap 10 Jun 2010}

4. Bellwood DR, Hughes TP, Folke C, Nyström M: Confronting the coral reef crisis. Nature 2004, 429:827-33.

5. Mumby PJ, Steneck RS: Coral reef management and conservation in light of rapidly evolving ecological paradigms. Trends Ecol Evol 2008, 23:555-63.

6. Gardner TA, Cote IM, Gill JA, Grant A, Watkinson AR: Long-term region-wide declines in Caribbean corals. Science 2003, 30I:958-60.

7. Bruno JF, Selig ER: Regional decline of coral cover in the IndoPacific: timing, extent, and subregional comparisons. PLoS One 2007, 2:e7II.

FI000 Factor 6.0 Must Read Evaluated by Alina Szmant 29 Aug 2007

8. Carpenter KE, Abrar M, Aeby G, Aronson RB, Banks S, Bruckner A, Chiriboga A, Cortés J, Delbeek JC, DeVantier L, Edgar GJ, Edwards AJ, Fenner D, Guzmán HM, Hoeksema BW, Hodgson G, Johan O, Licuanan WY, Livingstone SR, Lovell ER, Moore JA, Obura DO, Ochavillo D, Polidoro BA, Precht WF, Quibilan MC, Reboton C,
Richards ZT, Rogers AD, Sanciangco J, et al.: One-third of reefbuilding corals face elevated extinction risk from climate change and local impacts. Science 2008, 321:560-3.

9. Baker AC, Glynn PW, Riegl B: Climate change and coral reef bleaching: An ecological assessment of long-term impacts, recovery trends and future outlook. Estuar Coast Shelf Sci 2008, 80:435-7I.

10. Burkepile DE, Hay ME: Herbivore species richness and feeding complementarity affect community structure and function on a coral reef. Proc Natl Acad Sci U S A 2008, 105:1620I-6.

II. Hughes TP, Rodrigues MJ, Bellwood DR, Ceccarelli D, HoeghGuldberg O, McCook L, Moltschaniwskyj N, Pratchett MS, Steneck RS, Willis B: Phase shifts, herbivory, and the resilience of coral reefs to climate change. Curr Biol 2007, I7:360-5.

FI000 Factor 3.0 Recommended Evaluated by Peter Mumby 16 Apr 2007

12. Hoey AS, Bellwood DR: Limited Functional Redundancy in a High Diversity System: Single Species Dominates Key Ecological Process on Coral Reefs. Ecosystems 2009, I 2:1316-28.

13. Rasher DB, Hay ME: Chemically rich seaweeds poison corals when not controlled by herbivores. Proc Natl Acad Sci U S A 20I0, 107:9683-8.

14. Kuffner IB, Walters LJ, Becerro MA, Paul VJ, Ritson-Williams R, Beach KS: Inhibition of coral recruitment by macroalgae and cyanobacteria. Mar Ecol Prog Ser 2006, 323:107-17.

15. Birrell CL, McCook LJ, Willis BL, Diaz-Pulido GA: Effects of benthic algae on the replenishment of corals and the implications for the resilience of coral reefs. In Oceanography and Marine Biology: An Annual Review. Volume 46. Edited by Gibson RN, Atkinson RJA, Gordon JDM. London, UK: Taylor \& Francis; 2008:25-63.

16. Diaz-Pulido G, Harii S, McCook LJ, Hoegh-Guldberg O: The impact of benthic algae on the settlement of a reef-building coral. Coral Reefs 2010, 29:203-8.

17. Jones GP, McCormick MI, Srinivasan M, Eagle JV: Coral decline threatens fish biodiversity in marine reserves. Proc Natl Acad Sci U S A 2004, I0I:825I-3.

18. Wilson SK, Graham NAJ, Pratchett MS, Jones GP, Polunin NVC: Multiple disturbances and the global degradation of coral reefs: are reef fishes at risk or resilient? Glob Chang Biol 2006, 1 2:2220-34.

19. Lewis SM: The role of herbivorous fishes in the organization of a Caribbean reef community. Ecol Monogr 1986, 56:183-200.

20. Graham NAJ, McClannahan TR, MacNeil MA, Wilson SK, Polunin NVC, Jennings S, Chabanet P, Clark S, Spalding MD, Letourner Y, Bigot L, Galzin R, Ohman MC, Garpe KC, Edwards AJ, Sheppard CRC: Climate warming, marine protected areas and the oceanscale integrity of coral reef ecosystems. PLOS One 2008, 3:e3039.

FI000 Factor 6.0 Must Read

Evaluated by Andrew Baird 05 Feb 2010

21. Selig ER, Bruno JF: A global analysis of the effectiveness of marine protected areas in preventing coral loss. PLoS One 2010, 5:e9278.

22. Wooldridge SA, Done TJ: Improved water quality can ameliorate effects of climate change on corals. Ecol Appl 2009, 19: 1492-9.

23. Mumby PJ, Dahlgren CP, Harborne AR, Kappel CV, Micheli F, Brumbaugh DR, Holmes KE, Mendes JM, Broad K, Sanchirico JN, Buch K, Box S, Stoffle RW, Gill AB: Fishing, trophic cascades, and the process of grazing on coral reefs. Science 2006, $3 \mathrm{II}$ I:98- $10 \mathrm{I}$.

FI000 Factor 3.2 Recommended Evaluated by John Pandolfi 23 Jan 2006, Robert Paine 27 Jan 2006

24. Mumby PJ, Harborne AR, Williams J, Kappel CV, Brumbaugh DR, Micheli F, Holmes KE, Dahlgren CP, Paris CB, Blackwell PG: Trophic cascade facilitates coral recruitment in a marine reserve. Proc Natl Acad Sci U S A 2007, 104:8362-7.

FI000 Factor 6.0 Must Read

Evaluated by Jordi Bascompte 2I Jun 2007 
25. Mumby PJ, Harborne AR: Marine reserves enhance the recovery of corals on Caribbean reefs. PLoS One 2010, 5:e8657.

FI000 Factor 3.0 Recommended

Evaluated by John Pandolfi 02 Feb 2010

26. Raymundo LJ, Halford AR, Maypa AP, Kerr AM: Functionally diverse reef-fish communities ameliorate coral disease. Proc Natl Acad Sci U S A 2009, I06: I7067-70.

27. Carilli JE, Norris RD, Black BA, Walsh SM, McField M: Local stressors reduce coral resilience to bleaching. PLoS One 2009, 4:e6324.

28. Burkepile DE, Hay ME: Herbivore vs. nutrient control of marine primary producers: context-dependent effects. Ecology 2006, 87:3128-39.

29. Nugues MM, Smith GW, Hooidonk RJ, Seabra MI, Bak RPM: Algal contact as a trigger for coral disease. Ecol Lett 2004, 7:919-23.

FI000 Factor 3.0 Recommended

Evaluated by John Pandolfi 17 Dec 2004

30. Smith JE, Shaw M, Edwards RA, Obura D, Pantos O, Sala E, Sandin SA, Smriga S, Hatay M, Rohwer FL: Indirect effects of algae on coral: algae-mediated, microbe-induced coral mortality. Ecol Lett 2006, 9:835-45.

31. Russ GR, Alcala AC, Maypa AP, Calumpong HP, White AT: Marine reserves benefit local fisheries. Ecol Appl 2004, | 4:597-606.

32. Elmhirst T, Connolly SR, Hughes TP: Connectivity, regime shifts and the resilience of coral reefs. Coral Reefs 2009, 28:949-57.

33. Bellwood DR, Hughes TP, Hoey AS: Sleeping functional group drives coral-reef recovery. Curr Biol 2006, I 6:2434-9.

FI000 Factor 3.0 Recommended

Evaluated by Garry Peterson I5 Jan 2007

34. Lokrantz J, Nyström M, Thyresson M, Johansson C: The non-linear relationship between body size and function in parrotfishes. Coral Reefs 2008, 27:967-74.

35. Burkepile DE, Hay ME: Impact of herbivore identity on algal succession and coral growth on a Caribbean reef. PLoS One 2010, 5:e8963. 